\title{
Household behavior in practicing mental budgeting based on the theory of planned behavior
}

\author{
Ume Habibah ${ }^{1}$ D, Ibne Hassan ${ }^{2 *}$, Muhammad Shahid lqbal ${ }^{2}$ and Naintara ${ }^{3}$
}

\author{
* Correspondence: \\ ibnehassan@bzu.edu.pk \\ ${ }^{2}$ Department of Commerce, \\ Bahauddin Zakariya University, \\ Multan, Pakistan \\ Full list of author information is \\ available at the end of the article
}

\begin{abstract}
Ajzen's theory of planned behavior (TPB) suggests that planned behavior is determined by behavioral intention. Despite extensive literature based on TPB, household mental budgeting behavior explained by TPB is underexplored. The current study empirically tested TPB factors in light of mental budgeting behavior. The hypothesized model was tested using partial least squares structural equation modeling (PLS-SEM). PLS-SEM was employed using a Likert-scaled questionnaire administered to 275 households. The results indicate that mental budgeting attitude and mental budgeting past behavior strongly predict mental budgeting intention, and mental budgeting intention predicts mental budgeting behavior. Further, mental budgeting intention partially mediates the relationship between mental budgeting attitude and mental budgeting behavior, and mental budgeting past behavior and mental budgeting behavior. This study contributes to the academic interest in theoretical progress in household behavior.
\end{abstract}

Keywords: Mental budgeting behavior, Household budgeting behavior, Mental budgeting attitude, Mental budgeting past behavior, Mental budgeting intention

\section{Introduction}

"We can enrich our understanding of financial markets by adding a human element."

Thaler (1999)

As every student of behavioral finance knows, explaining mental accounting (MA) in all of its complexities is a difficult task. Different researchers have approached mental accounting in different dimensions. For example, Thaler (1985) and Thaler and Johnson (1990) approached it in terms of hedonic editing. Henderson and Peterson (1992) studied gains and losses categorization, Shefrin and Thaler (1988) investigated income and assets labeling and earmarking, and Thaler (1985) studied borrowing and saving simultaneously. Thaler (1999), moreover, approached mental accounting in terms of transaction utility and acquisition utility, while Kivetz (1999) and Prelec and Loewenstein (1998) studied payment decoupling. Arkes and Blumer (1985), Shafir and Thaler (2006), Soman (2001), and Thaler (1999) studied the sunk cost phenomenon, and Read, Loewenstein, Rabin, Keren, and Laibson (1999) and Thaler (1999) studied choice bracketing. Finally, Heath and Soll (1996) approached mental accounting in the dimension of budgeting and provided a theory of mental budgeting.

(c) The Author(s). 2019 Open Access This article is distributed under the terms of the Creative Commons Attribution 4.0 International License (http://creativecommons.org/licenses/by/4.0/), which permits unrestricted use, distribution, and reproduction in any medium, provided you give appropriate credit to the original author(s) and the source, provide a link to the Creative Commons license, and indicate if changes were made. 
Mental budgeting (Heath \& Soll, 1996) is the psychological separation of the household budget. Within specific mental budget accounts, negative balances are avoided via the process of mental budgeting. Individuals avoid having a negative balance in any mental budget account. For example, households may keep three different mental budgets: food budget, outing budget, and savings budget. They allocate a certain amount/portion of money to each budget depending on the objective of developing that budget. Sources of money also affect the allocation of money to mental budgets, which are kept mentally separate from each other. Based on laboratory experiments where respondents were presented with scenarios, Heath and Soll (1996) reported that when a particular household budget becomes exhausted, people say they will spend less in that particular category at the end of the month. Meanwhile, Soman (2001), Soman (2003), and Soman and Lam (2002) found that an upcoming purchase in a particular budget category becomes unlikely when the previously paid amount was in the form of paper money, not plastic.

Mental budgeting is important for households for a couple reasons. First, it affects consumer decisions (Heath and Soll, 1996) such that a consumer may underconsume in a specific category if he or she made an unplanned purchase that is highly typical of that category. Also, people might often engage in mental budgeting processes to control their spending behavior and avoid debt (Bénabou \& Tirole, 2004; Chattoe \& Gilbert, 1999; Thaler, 1999). Similarly, households might perform mental budgeting to acquire savings. As Thaler $(1985,1999)$ noted, low-income consumers might be especially likely to make mental budgets, which in turn can affect whether savings are accrued.

Prior literature has shown how mental budgeting is related to household finances, but a question remains about which factors predict mental budgeting behavior. This study, therefore, aimed to explain the household behavior of managing finances while practicing mental budgeting based on the theory of planned behavior (TPB). Mental budgeting is involved in household money (finance) management (Antonides, de Groot, \& van Raaij, 2011), which is the most important factor in financial capability (Atkinson, McKay, Kempson, \& Collard, 2006). To investigate the determinants of mental budgeting behavior, we first present a brief overview of the theory of planned behavior (Ajzen, 1985, 1987, 1991). This study also extends the literature on TPB by empirically testing whether a modified TPB can explain mental budgeting behavior. Hypotheses are developed in next section. We then present the data collection tools, describe the data collection, and report the empirical results. The final section concludes the paper with some recommendations and future research directions.

\section{Theory of planned behavior}

Ajzen $(1985,1987,1991)$ proposed the theory of planned behavior (TPB). The main theme of this theory is that behavioral intention is the best way to predict and explain a person's behavior. Behavioral intention, meanwhile, is determined by attitude, subjective norms, and perceived behavioral control (Ajzen and Madden, 1986). Ajzen's (1991) TPB has been used to predict an array of behaviors. Table 1 lists a few studies that suggest that TPB can predict financial behavior. 
Table 1 Recent Literature summary of TPB applicability

\begin{tabular}{ll}
\hline Area of studv & References \\
\hline Tourism & (Jalilvand \& Samiei, 2012; Pan \& Truong, 2018) \\
Islamic Banking & (Kashif, Zarkada, \& Ramayah, 2018) \\
Gambling behavior & (Martin et al., 2010) \\
Smoking & (De Wilde et al.,2017) \\
Social networking & (Tariq, Sajjad, Usman, \& Amjad. 2017) \\
Physical activity & (Brooks et al., 2017) \\
Service Quality & (Shahid lqbal, U1 Hassan, \& Habibah, 2018) \\
Environmental behavior & (Kim, Njite, \& Hancer, 2013) \\
Entrepreneurial behavior & (Kautonen, van Gelderen, \& Fink, 2015) \\
Eating behavior & (Close, Lytle, Chen, \& Viera, 2018) \\
Education & (Sutter \& Paulson, 2017) \\
Suicidal Intent & (George, 2008) \\
Game playing & (Alzahrani, Mahmud, Ramayah. Alfarraj, \& Alalwan, 2017)
\end{tabular}

Later, Forward (2009) summarized prior studies suggesting that subjective norms have a poor impact because the normative measure is too narrow (Rivis, Sheeran, \& Armitage, 2006). In 1998, Armitage and Conner (2001) extended the theory of planned behavior by providing empirical and theoretical evidence to support adding more variables to the TPB; one was past behavior. The prediction ability of intention has been empirically tested in many studies, and Armitage and Conner (2001) and Sheeran and Taylor (1999) conducted meta-analyses. They found that there was an improvement of $5-12 \%$ in variance explained when a third direct measure, perceived behavioral control, was added to the model.

Despite the extensive literature on the applicability of TPB, household mental budgeting behavior prediction through TPB is still unexplored. This study, therefore, aimed to explain the mental budgeting behavior of Pakistani households in view of TPB. The next section develops the hypotheses.

\section{Hypothesis development}

Mental budgeting attitude and mental budgeting intention

Attitude is an important factor in both the theory of reasoned action (Fisbein and Ajzen, 1975) and the theory of planned behavior (Ajzen, 1985, 1987). Attitude directly predicts intention and indirectly predicts behavior. Fisbein and Ajzen (1975) classified attitude as attitude toward object and attitude toward specific behavior. Attitude toward object is a function of the individual's belief toward the object and the individual's implicit evaluation of his or her beliefs, and attitude toward behavior is a function of the perceived consequences of performing the behavior of interest and the individual's subjective evaluation of the consequences.

Attitude is defined as the degree of an individual's positive or negative feelings toward a particular object or toward the intention to perform a particular behavior (Ajzen \& Fishbein, 2000). Intention, meanwhile, is defined as instructions people give to themselves to behave in certain ways (Triandis, 1980). In the domain of mental budgeting, if there is a favorable attitude toward budgets, there will be a more favorable attitude 
toward making mental budgets, thus increasing the likelihood of behavioral intention and the displaying of the behavior.

Studying the relationship stability between attitude and intention in the context of mental budgeting is important because mental budgeting behavioral interventions are formed when attitude manipulation has a maximal effect on intention. Studies have found evidence of a significant direct relationship between attitudes and behavioral intention (Ajzen \& Fishbein, 2000; Armitage \& Conner, 2001; Cameron, 2010; Close et al., 2018; Kashif et al., 2018; Tariq et al., 2017). Thus, hypothesis 1 is proposed:

H1: Attitude toward making mental budgets will be positively related to the intention to make mental budgets.

\section{Mental budgeting past behavior and mental budgeting intention}

Honkanen, Olsen, and Verplanken (2005) posited that intention is strongly influenced by past behavior. Prior studies (e.g., Bagozzi, 1981; Bentler \& Speckart, 1979; Fredricks \& Dossett, 1983; Triandis, 1980) have indicated that past behavior is a good predictor of behavior compared to TPB constructs (i.e., subjective norms, attitudes, and perceived behavioral control). When a person enters into a behavior, that person is, for getting involved in that particular behavior, more likely to build an intention. This is done without considering the other variables in TPB (attitudes, subjective norms, and perceived behavioral control). The reason is that behavior-related specifications remain the same. In this situation, the expectation of intention based on past behavior will reduce the influence of social cognitive variables such as attitude, subjective norms, and perceived behavioral control (Hagger, Chatzisarantis, \& Biddle, 2001). Bagozzi and Kimmel (1995) affirmed the influences of past behavior. They argued that the direction of future target behavior is controlled by prior decision-making processes. First, a person decides to get involved in a behavior, and then he or she enters into that behavior.

Evidence has indicated that past behavior directly affects current behavior occurrence, even when TPB cognitions are considered (Conner \& Abraham, 2001; De Bruijn et al., 2007; Hagger et al., 2001; Jackson, Smith, \& Conner, 2003; Norman \& Smith, 1995; Rhodes \& Courneya, 2003). In the domain of mental budgeting, past behavior shows how many times households made mental budgets. Thus, hypothesis 2 is proposed:

$\mathrm{H} 2$ : Mental budgeting past behavior will be positively related to intention to make mental budgets.

\section{Mental budgeting intention and mental budgeting behavior}

Intention is defined as the likelihood an actor consciously assigns to engaging in a particular behavior (Ajzen, 1991; Ajzen \& Fishbein, 1980; Fisbein and Ajzen, 1975). Intention is considered a motivational variable and a context-specific representation of goal-directed behavior (Bloom, 2000).

Different studies have examined the relationship between intention and behavior in different domains (e.g., Athiyaman, 2002; Sheeran \& Orbell, 2000; Tariq et al., 2017; Warshaw \& Davis, 1984) and have suggested that intention is a significant predictor of behavior.

In the present study, mental budgeting intentions, as suggested by the authors, are instructions or motivations that households give themselves to make mental budgets. It 
is proposed that mental budgeting behavior is predicted by mental budgeting intention. Hypothesis 3 is thus proposed:

H3: Mental budgeting intention predicts mental budgeting behavior.

As stated earlier, mental budgeting intention is a function of mental budgeting attitude and mental budgeting past behavior ( $\mathrm{H} 1$ and $\mathrm{H} 2)$, and mental budgeting behavior is a function of mental budgeting intention (H3). This leads to two more hypotheses related to the mediation of mental budgeting intention:

H4: Mental budgeting intention mediates the relationship between mental budgeting attitude and mental budgeting behavior.

H5: Mental budgeting intention mediates the relationship between mental budgeting past behavior and mental budgeting behavior.

\section{Data analysis techniques}

Structural equation modeling (SEM) is a second-generation multivariate analysis technique. It is used to test the linkages between constructs (Gefen, Straub, \& Boudreau, 2000; Hair Jr, Hult, Ringle, and Sarstedt, 2013). Two different but complementary statistical methods for estimating structural models are partial least squares (PLS) SEM (which is variance based) and covariance-based (CB) SEM (Hair Jr et al., 2013). CB-SEM is used for confirmatory research with a sufficient theoretical base to test the theory when the sample size is large (200-800). Meanwhile, for exploratory research (also for confirmatory research with an insufficient theoretical base), for prediction purposes, when the sample size is small, PLS-SEM is applied. This study met all of the criteria for using PLS-SEM.

The model (Fig. 1) used for this research involves multiple constructs. PLS-SEM is more rigorous compared to regression analysis for testing measurement and structural components simultaneously (Hair Jr et al., 2013; Henseler et al., 2009). Further, PLS-SEM seems more appropriate because some CB-SEM assumptions cannot be observed (Hulland, Ryan, \& Rayner, 2010).

PLS-SEM is more appropriate if models and measures in any field are in the early stages of development (Fornell \& Bookstein, 1982; Hair Jr et al., 2013). Current study is intended to explain TPB in a new context named as mental budgeting behavior. As such, the relationships between mental budgeting attitude, mental budgeting past behavior, mental budgeting intention, and mental budgeting behavior were tested for the first time; therefore, PLS-SEM was used.

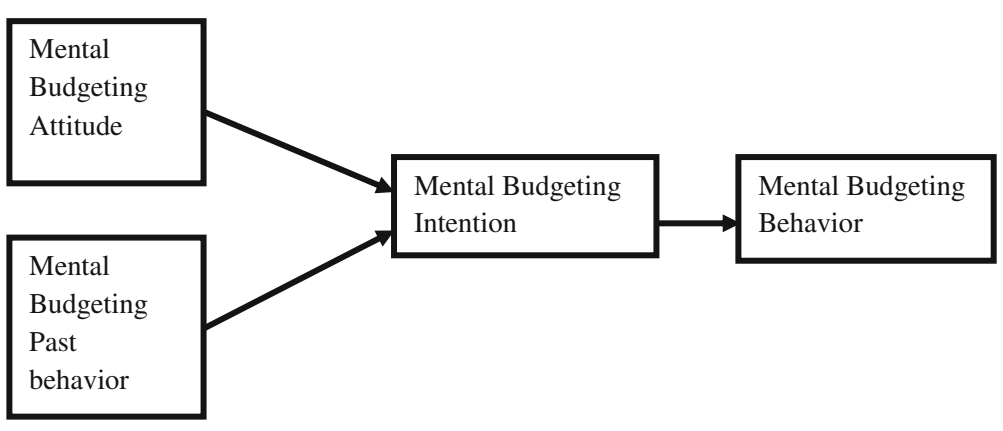

Fig. 1 Determinants of Mental Budgeting Behavior 
Since this study used PLS-SEM (Hair, Sarstedt, Ringle, \& Mena, 2012), the minimum sample size required for the conceptual model through SmartPLS was 30. The "rule of ten" was applied, as suggested by Hair et al. (2011), to determine the sample size and test the model using PLS-SEM. According to this rule, "the minimum sample size should be ten times the highest number of structural paths directed at a latent construct at a time" (Hair et al., 2011, p. 144). The sample for this study consisted of 275 respondents.

Univariate analysis was conducted to determine the central tendency and dispersions in the data set. Skewness and kurtosis were also tested for normal data distribution. While PLS-SEM modeling does not consider assumptions about data distribution, it is worthwhile to examine distributional properties (Hair Jr et al., 2013).

Further, bootstrapping was applied to test the statistical significance of various PLS-SEM results, including path coefficients. PLS-SEM does not assume data normality, which implies that parametric testing cannot be used to test statistical significance; rather, nonparametric tests are applied-that is, bootstrapping. In this procedure, subsamples are created with observations randomly drawn from the original data set with replacement. To ensure the stability of results, the number of subsamples should be large; in our case, the number of subsamples was 500 .

\section{Sample and design}

Fraenkel and Wallen (2003) defined a population as a group to which results are applied. The present study concerned mental budgeting behavior and its determinants in how Pakistani households decide upon their budgeting behavior. Thus, the population for this study was employed households. Considering the feasible population, the Southern Punjab in Pakistan was taken as the target population, and purposive sampling (a subtype of nonrandom sampling) was undertaken for sampling purposes. The questionnaire contained a brief introduction to household mental budgeting behavior. Data were collected only from employed households through self-administered and online surveys. A total of 289 questionnaires were collected. Online responses represented only $0.021 \%$ of the total responses. Fourteen questionnaires were excluded because of incomplete responses. Respondents who did not disclose any demographic information were kept for analysis purposes. Raw data were entered for a total of 275 questionnaires. Data were screened for validity after compilation.

\section{Data collection instruments}

Primary sources were utilized for the purposes of data collection. A closed-ended questionnaire (see Additional file 2) was used to collect the responses. A total of 24 questions were on the questionnaire, including 12 demographic and 12 closed-ended questions. Respondents were asked to rate the constructs of the study-namely, mental budgeting attitude, mental budgeting past behavior, mental budgeting intention, and mental budgeting behavior.

Mental budgeting attitude was measured by four questions adapted from Kidwell and Turrisi (2004). A response of 1 indicated unfavorable, bad, unsatisfactory, or negative; 5 meant favorable, good, satisfactory, or positive. 
Items were adapted from Antonides et al. (2011) to measure mental budgeting behavior. Four items were included in the mental budgeting scale. If individuals are observing mental budgeting in their lives, it is assumed they are exercising mental budgeting behavior. So, the scale for mental budgeting was used as a proxy for mental budgeting behavior. Each item ranged from 1 to 5: 5 for strongly agree, 4 for agree, 3 for neutral, 2 for disagree, and 1 for strongly disagree.

Past behavior was measured by one item ((Ajzen I: Constructing a theory of planned behavior questionnaire, Unpublished); Sheeran \& Orbell, 1996). Respondents were asked, "How often during the past year have you made mental budgets?" Responses were recorded as 1 for never and 5 for always. Single-item constructs are easily handled by PLS-SEM with no identification problems (Hair Jr et al., 2013). Mental budgeting intention was measured by asking three questions (Mathieson, 1991). The instrument of intention was same as in TPB. Responses were recorded on 5-point Likert scale.

\section{Results}

\section{Respondents' characteristics}

The questionnaire contained questions about personal information: gender, age (years), marital status, educational level, working experience (years) in current organization, qualification, and monthly income. The summarized demographic results are presented in Table 2. NR in the table stands for respondents who did not disclose their personal data. The descriptive statistics shown in Additional file 1 indicate that mental budgeting attitude and mental budgeting past behavior were stronger among respondents compared to their mental budgeting intention and behavior.

\section{Estimation of outer measurement model}

Stage one in the estimation of the outer measurement model included indicator reliability measurement through factor (outer) loadings, internal reliability measurement through composite reliability, convergent validity measurement through average variance extracted, and discriminant validity measurement through the Fornell-Larcker

Table 2 Demographic characteristics of respondents

\begin{tabular}{lllllllll}
\hline Gender & $\mathrm{N}$ & $\%$ & Marital status & $\mathrm{N}$ & $\%$ & Experience (Years) & $\mathrm{N}$ & $\%$ \\
\hline Female & 164 & $59.64 \%$ & Married & 143 & $52 \%$ & 5 or less & 165 & $60 \%$ \\
Male & 111 & $40.36 \%$ & Unmarried & 108 & $39.28 \%$ & 5 to 15 & 81 & $29.45 \%$ \\
& & & Divorced & 1 & $0.36 \%$ & 15 to 25 & 19 & $6.91 \%$ \\
& & & NR & 23 & $8.36 \%$ & More than 25 & 10 & $3.64 \%$ \\
Total & 275 & $100 \%$ & Total & 275 & $100 \%$ & Total & 275 & $100 \%$ \\
Qualification & $\mathrm{N}$ & $\%$ & Age (Years) & $\mathrm{N}$ & $\%$ & Income (,000) & $\mathrm{N}$ & $\%$ \\
Intermediate and below & 19 & $6.90 \%$ & $21-30$ & 155 & $56.36 \%$ & 10 \& below & 65 & $23.64 \%$ \\
undergraduate & 80 & $29.1 \%$ & $31-40$ & 76 & $27.64 \%$ & 10 to 20 & 68 & $24.73 \%$ \\
graduate & 149 & $54.18 \%$ & $41-50$ & 28 & $10.18 \%$ & 20 to 30 & 41 & $14.91 \%$ \\
postgraduate & 21 & $7.64 \%$ & $50+$ & 10 & $3.64 \%$ & 30 to 40 & 23 & $8.36 \%$ \\
NR & 6 & $2.18 \%$ & NR & 6 & $2.18 \%$ & 40 to 50 & 38 & $13.82 \%$ \\
& & & & & & $50 \&$ more & 40 & $14.54 \%$ \\
Total & 275 & $100 \%$ & Total & 275 & $100 \%$ & Total & 275 & $100 \%$ \\
\hline
\end{tabular}


criterion. The values are shown in Table 3. The table shows that all of the indicators had outer loadings of more than 0.50 (range: $0.637-1.000$ ), which is the value recommended by Nunnally (1978) and Hair, Black, Babin, Anderson, and Tatham (2006).

All of the constructs obtained composite reliability values (range: 0.855-1.000) greater than 0.80, which is the value recommended by Peter (1979). Meanwhile, Fornell and Larcker (1981), Nunnally and Bernstein (1994), and Hair et al. (2006) recommended 0.70 as the statistical criterion for composite reliability. Table 3 shows that the Cronbach's alpha ranges from 0.777 to 1.000 ; the statistically acceptable minimum value is 0.70 (Hair et al., 2006; Nunnally, 1978; Nunnally \& Bernstein, 1994). Barclay, Higgins, and Thompson (1995) and Hair et al. (2006) suggested that AVE values should be greater than 0.50 . Our results meet this criterion.

The threshold for the Fornell-Larcker criterion is that the square-root of the AVE should be more than the correlations of latent variables (Hair et al., 2006). Table 4 shows the Fornell-Larcker criterion.

\section{Estimation of inner measurement model}

Inner structural modeling estimates the relationships between constructs. This is measured through the coefficient of determination ( $r$-square); the size of the standardized path coefficients, called beta $\beta$; and path significance ( $p$-value). The results show that the $r$-square values and adjusted $r$-square values (see Table 3 ) are greater than the recommended value (0.20) suggested by Hair Jr. et al. (2013) (since the present study concerns household mental budgeting behavior). Table 5 shows the values for the regression weights $(\beta)$, standard errors, $t$-statistics, and $p$-values.

The empirical results for $\mathrm{H} 1(\beta=0.308, t=2.767, p<0.01)$ confirm that mental budgeting attitude directly predicts mental budgeting intention. The empirical results for $\mathrm{H} 2(\beta=0.328, t=3.264, p<0.001)$ confirm that mental budgeting past behavior significantly predicts mental budgeting intention. The empirical results for $\mathrm{H} 3(\beta=0.404, t=$ 5.727, $\mathrm{p}<0.01)$ confirm that mental budgeting intention directly predicts mental

Table 3 Values of outer loadings, CR, Cronbach alpha, AYE, R square and adjusted R square

\begin{tabular}{|c|c|c|c|c|c|c|c|}
\hline Latent variable & Indicators & Outer loadings & $\begin{array}{l}\text { Composite } \\
\text { Reliability }\end{array}$ & Cronbach's Alpha & AVE & R-sq. & $\begin{array}{l}\text { Adjusted } \\
\text { R-sq. }\end{array}$ \\
\hline \multirow[t]{4}{*}{ MB Attitude } & MBA1 & 0.893 & \multirow[t]{4}{*}{0.946} & \multirow[t]{4}{*}{0.924} & \multirow[t]{4}{*}{0.814} & \multirow[t]{4}{*}{-} & \multirow[t]{4}{*}{-} \\
\hline & MBA2 & 0.931 & & & & & \\
\hline & $\mathrm{MB} A 3$ & 0.880 & & & & & \\
\hline & MBA4 & 0.905 & & & & & \\
\hline \multirow[t]{4}{*}{ MB Behavior } & MBB1 & 0.823 & \multirow[t]{4}{*}{0.855} & \multirow[t]{4}{*}{0.777} & \multirow[t]{4}{*}{0.598} & \multirow[t]{4}{*}{0.323} & \multirow[t]{4}{*}{0.320} \\
\hline & MBB2 & 0.637 & & & & & \\
\hline & MBB3 & 0.760 & & & & & \\
\hline & MBB4 & 0.856 & & & & & \\
\hline \multirow[t]{3}{*}{ MB Intention } & MBI1 & 0.902 & \multirow[t]{3}{*}{0.913} & \multirow[t]{3}{*}{0.858} & \multirow[t]{3}{*}{0.778} & \multirow[t]{3}{*}{0.347} & \multirow[t]{3}{*}{0.342} \\
\hline & MBI2 & 0.917 & & & & & \\
\hline & $\mathrm{MBI3}$ & 0.825 & & & & & \\
\hline MB Past Behavior & MBPA1 & \multicolumn{2}{|c|}{ Single Item Construct } & & & - & - \\
\hline
\end{tabular}


Table 4 Fomell-Larcker criterion

\begin{tabular}{llccc}
\hline & MB Attitude & MB Behavior & MB Intention & MB Past Behavior \\
\hline MB Attitude & 0.902 & & & \\
MB Behavior & 0.372 & 0.773 & & \\
MB Intention & 0.542 & 0.568 & 0.882 & 1.000 \\
MB Past Behavior & 0.715 & 0.387 & 0.548 & \\
\hline
\end{tabular}

budgeting behavior. Figure 2 shows the results of the inner and outer measurement models.

\section{Mediation analysis}

Baron and Kenny (1986) argued for simultaneously considering direct and indirect effects to conclude mediation tests. We found that the direct effects of the independent variables (mental budgeting attitude and mental budgeting past behavior) on the dependent variable (mental budgeting behavior) were positive and statistically significant $(\beta=0.204, t=1.926, p<0.10 ; \beta=0.241, t=2.592, p<0.05$, respectively). The indirect effects in the presence of the mediator (mental budgeting intention) were also statistically significant $(\beta=0.175, t=2.710, \mathrm{p}<0.01 ; \beta=0.187, t=3.081, p<0.010$, respectively). This shows partial mediation. The mediation results are summarized in Table 6.

\section{Discussion}

The results of this study suggest that attitude influences households' intention to engage in mental budgeting. Thus, H1 is supported. This finding aligns with many earlier studies that found that attitude is an important determinant of intention (e.g., Ajzen \& Fishbein, 2000; Armitage \& Conner, 2001; Cameron, 2010; Close et al., 2018; Kashif et al., 2018; Tariq et al., 2017).

The present study's findings reveal that when people have positive, satisfactory, good, or favorable feelings about mental budgeting, they are more likely to have the intention to make mental budgets. Meanwhile, when people have negative, unsatisfactory, bad, or unfavorable feelings about mental budgeting, they are less likely to have the intention to make mental budgets.

The results also suggest that favorable and satisfactory mental budgeting attitudes can enhance mental budgeting behavioral intention, thus bringing about actual behavior toward mental budgeting among households. Attitude was shown to be positively related to intention, but this relation was weaker than those of past behavior-intention relations, which is in line with Honkanen et al. (2005) and Verbeke and Vackier (2005). Trafimow and Borrie (1999) found that past behavior might have a priming effect on

Table 5 Results of Structural Model

\begin{tabular}{|c|c|c|c|c|c|c|}
\hline \multicolumn{2}{|c|}{ Hypotheses } & \multirow{2}{*}{$\begin{array}{l}\text { Path coefficient } \beta \\
0.308\end{array}$} & \multirow{2}{*}{$\begin{array}{l}\text { Standard Error } \\
.106\end{array}$} & \multirow{2}{*}{$\frac{\text { t statistics }}{2.890}$} & \multirow{2}{*}{$\begin{array}{l}P \text { values } \\
.004\end{array}$} & \multirow{2}{*}{$\begin{array}{l}\text { Remarks } \\
\text { Supported }\end{array}$} \\
\hline $\mathrm{Hi}$ & MB Attitude $\rightarrow$ MB Intention & & & & & \\
\hline $\mathrm{H} 2$ & MB Past Behavior $\rightarrow$ MB Intention & 0.328 & .099 & 3.332 & .001 & Supported \\
\hline $\mathrm{H} 3$ & MB Intention $\rightarrow$ MB Behavior & 0.568 & .051 & 11.041 & .000 & Supported \\
\hline
\end{tabular}




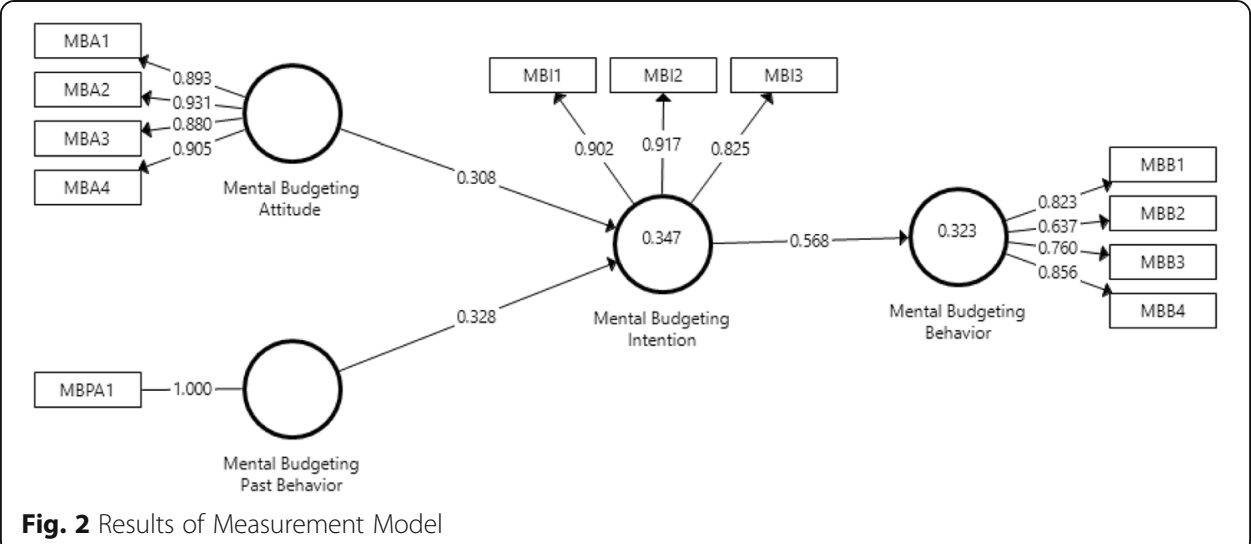

future behavioral intention, making past behavior a predictor of intention to perform behavior later.

Trafimow and Borrie (1999) reasoned that performing a behavior repeatedly increases its cognitive accessibility, which again affects the intention to perform that behavior. The present study obtained the same finding since a strong relationship was found between mental budgeting past behavior and mental budgeting intention. Thus, $\mathrm{H} 2$ is supported-that is, in the case of household mental budgeting, when the past frequency of making mental budgets increases, it positively affects the intention toward mental budgeting. Increased past frequency increases cognitive accessibility, which affects the intention to perform mental budgeting behavior.

The results also demonstrated a strong relationship between mental budgeting intention and mental budgeting behavior. This aligns with previous studies showing that intention predicts later behavior (e.g., Athiyaman, 2002; Sheeran \& Orbell, 2000; Tariq et al., 2017; Warshaw \& Davis, 1984). When households have a strong intention toward mental budgeting, they ultimately perform it. Thus, we can conclude that the theory of planned behavior can predict mental budgeting behavior among Pakistani households. Further, we provide evidence showing that mental budgeting intention is a mediator between mental budgeting attitude and mental budgeting behavior, and mental budgeting past behavior and mental budgeting behavior.

\section{Conclusion}

This study aimed to explain the behavior of households when practicing mental budgeting behaviors. The explanation was based on the theory of planned behavior. We found that attitude and past behavior toward mental budgeting behavior significantly influenced mental budgeting behavioral intention. The results also showed that mental budgeting occurs frequently among young households in the Southern Punjab.

Most households showed positive attitudes toward mental budgeting. Mental budgeting has long entered into the daily lives of households. The findings also showed that households generally had satisfactory, positive, and favorable attitudes toward the intention to make budgets. We can conclude that when households have favorable feelings about mental budgeting, they instruct themselves to make mental budgets. When people have unfavorable feelings about mental budgets, they do not instruct themselves 
Table 6 Mediation analysis

\begin{tabular}{|c|c|c|c|c|c|c|}
\hline \multicolumn{2}{|c|}{ Hypotheses } & \multirow{2}{*}{$\frac{\text { Direct effect }}{0.204}$} & \multirow{2}{*}{$\frac{P \text { values }}{.055}$} & \multirow{2}{*}{$\frac{\text { Indirect effect }}{0.175}$} & \multirow{2}{*}{$\frac{P \text { values }}{0.007}$} & \multirow{2}{*}{$\frac{\text { Remarks }}{\text { Partial Mediation }}$} \\
\hline $\mathrm{H} 4$ & MB Attitude $\rightarrow$ MB Behavior & & & & & \\
\hline 45 & MB Past behavior $\rightarrow$ MB Behavior & 0.241 & .010 & 0.187 & 0.002 & Partial Mediation \\
\hline
\end{tabular}

to make mental budgets. In this study, overall attitude was taken as a measure. Future research could expand attitude as per its bipolar attributes.

This study suggests that households in the Southern Punjab in Pakistan actively manage their budgets in the performance of consumer behavior. This finding is more suitable for young households. This study also contributes to the literature by adding the determinants of household mental budgeting behavior in light of TPB (Ajzen, 1991). This study generalized the factors of TPB on mental budgets. Previous studies, meanwhile, have determined the factors affecting money management behavior among college students (Kidwell, Brinberg, \& Turrisi, 2003). The present study also contributes to the literature by investigating household mental budgeting behavior. Moreover, this study found that households might do mental budgeting because they are more interested in generating savings (Fisher \& Anong, 2012; Xiao \& Fan, 2002).

This study does have some limitations. The first is related to sample size. Although the sample size $(n=275)$ was large enough to use PLS-SEM (Hair Jr. et al., 2013), employed households were underrepresented. Second, this study was a first attempt to predict mental budgeting behavior based on TPB; thus, the PLS-SEM approach was used because the main purpose was to predict the determinants of mental budgeting behavior (Hair et al., 2011; Hair Jr. et al., 2013). PLS-SEM is based on nonparametric measures and does not consider distributional assumptions for parametric estimation (Chin, 1998; Hair Jr. et al., 2013). Future research should begin with a scoping study as the basis to form a theoretical framework and use a large-scale survey utilizing the CB-SEM approach to address the limitations of PLS-SEM, thereby confirming (or rejecting) the model proposed for determining mental budgeting behavior. Furthermore, younger respondents (21-30 years old) were overrepresented in the sample. For more comprehensive results, future research should collect data from respondents over age 30. In addition, stratified and cluster sampling are also recommended for future studies.

\section{Additional files}

Additional file 1: Statistical Results of Mean, Standard Deviation, Skewness and Kurtosis. (DOCX 14 kb)

Additional file 2: Survey Questionnaire. (DOCX $24 \mathrm{~kb}$ )

Abbreviations

AVE: Average Variance Extracted; CB-SEM: Covariance Based-Structural Equation Modelling; MB: Mental Budgeting; NR: Non response; PLS-SEM: Partial Least Square-Structural Equation Modelling; TPB: Theory of Planned Behavior

Acknowledgements

Not applicable.

Funding

The authors received no direct funding for this research. 


\section{Authors' contributions}

First and Corresponding Author, UH came up with the idea of study. She performed the analysis and completed the whole draft. Second author, $\mathrm{IH}$ reviewed the paper and gave his insightful thoughts during the whole journey of this study. Third Author, MSI and Fourth Author, $\mathrm{N}$ helped for data collection. All authors read and approved the final manuscript.

\section{Ethics approval and consent to participate}

Not Applicable.

\section{Competing interests}

Authors declare that they have no competing interests.

\section{Publisher's Note}

Springer Nature remains neutral with regard to jurisdictional claims in published maps and institutional affiliations.

\section{Author details}

'Department of Management Sciences, Air University Multan Campus, Multan, Pakistan. ${ }^{2}$ Department of Commerce, Bahauddin Zakariya University, Multan, Pakistan. ${ }^{3}$ Bahauddin Zakariya University, Multan, Pakistan.

Received: 28 October 2017 Accepted: 8 October 2018

Published online: 02 November 2018

\section{References}

Ajzen I (1985) From intentions to actions: a theory of planned behavior. In J. Kuhl \& J. Beckmann (Eds.), Action-control: From cognition to behavior (pp. 1 I-39). Heidelberg: Springer.

Ajzen I (1987) Attitudes, traits, and actions: dispositional prediction of behavior in personality and social psychology. Adv Exp Soc Psychol 20(1):1-63.

Ajzen I (1991) The theory of planned behavior. Organ Behav Hum Decis Process 50(2):179-211.

Ajzen, I., \& Fishbein, M. (1980). Understanding attitudes and predicting social behaviour.

Ajzen I, Fishbein M (2000) Attitudes and the attitude-behavior relation: reasoned and automatic processes. Eur Rev Soc Psychol 11(1):1-33.

Ajzen I, Madden TJ (1986) Prediction of goal-directed behavior: attitudes, intentions, and perceived behavioral control. J Exp Soc Psychol 22(5):453-474.

Alzahrani Al, Mahmud I, Ramayah T, Alfarraj O, Alalwan N (2017) Extending the theory of planned behavior (TPB) to explain online game playing among Malaysian undergraduate students. Telematics Inform 34(4):239-251.

Antonides G, de Groot IM, van Raaij WF (2011) Mental budgeting and the management of household finance. J Econ Psychol 32(4):546-555.

Arkes HR, Blumer C (1985) The psychology of sunk cost. Organ Behav Hum Decis Process 35(1):124-140.

Armitage CJ, Conner M (2001) Efficacy of the theory of planned behaviour: a meta-analytic review. Br J Soc Psychol 40(4): 471-499.

Athiyaman A (2002) Internet users' intention to purchase air travel online: an empirical investigation. Mark Intell Plan 20(4): 234-242.

Atkinson A, McKay S, Kempson E, Collard S (2006) Levels of financial capability in the UK: results of a baseline survey. Financial Services Authority, UK.

Bagozzi RP (1981) Attitudes, intentions, and behavior: a test of some key hypotheses. J Pers Soc Psychol 41(4):607.

Bagozzi RP, Kimmel SK (1995) A comparison of leading theories for the prediction of goal-directed behaviours. Br J Soc Psychol 34(4):437-461.

Barclay D, Higgins C, Thompson R (1995) The partial least squares (PLS) approach to causal modeling: personal computer adoption and use as an illustration. Technol Stud 2(2):285-309.

Baron RM, Kenny DA (1986) The moderator-mediator variable distinction in social psychological research: conceptual, strategic, and statistical considerations. J Pers Soc Psychol 51(6):1173.

Bénabou R, Tirole J (2004) Willpower and personal rules. J Polit Econ 112(4):848-886.

Bentler PM, Speckart G (1979) Models of attitude-behavior relations. Psychol Rev 86(5):452.

Bloom L (2000) Intentionality and theories of intentionality in development. Hum Dev 43(3):178-185.

Brooks, J. M., Iwanaga, K., Chiu, C.-Y., Cotton, B. P., Deiches, J., Morrison, B., . . Chan, F. (2017). Relationships between selfdetermination theory and theory of planned behavior applied to physical activity and exercise behavior in chronic pain. Psychol Health Med, 22(7), 814-822.

Cameron, R. (2010). Ajzen's theory of planned behavior applied to the use of social networking by college students.

Chattoe E, Gilbert N (1999) Talking about budgets: time and uncertainty in household decision making. Sociology 33(1):085-103.

Chin WW (1998) The partial least squares approach to structural equation modeling. Modern Methods Business Res 295(2): 295-336.

Close MA, Lytle LA, Chen D-G, Viera AJ (2018) Using the theory of planned behavior to explain intention to eat a healthful diet among southeastern United States office workers. Nutrition Food Sci 48(2).

Conner M, Abraham C (2001) Conscientiousness and the theory of planned behavior: toward a more complete model of the antecedents of intentions and behavior. Personal Soc Psychol Bull 27(11):1547-1561.

De Bruijn G-J, Kremers SP, De Vet E, De Nooijer J, Van Mechelen W, Brug J (2007) Does habit strength moderate the intention-behaviour relationship in the theory of planned behaviour? The case of fruit consumption. Psychol Health 22(8):899-916. 
De Wilde K, Maes L, Boudrez H, Tency I, Temmerman M, Clays E (2017) Analysis of smoking cessation beliefs in pregnant smokers and ex-smokers using the theory of planned behavior. J Public Health 25(3):267-274.

Fisbein M, Ajzen I (1975) Belief, attitude, intention and behavior: an introduction to theory and research. Addison-Wiley Publishing Company, Massachusetts.

Fisher PJ, Anong ST (2012) Relationship of saving motives to saving habits. J Finan Counsel Plann Vol 23(1):64.

Fornell C, Bookstein FL (1982) Two structural equation models: LISREL and PLS applied to consumer exit-voice theory. J Mark Res 19(4):440-452.

Fornell C, Larcker DF (1981) Evaluating structural equation models with unobservable variables and measurement error. J Mark Res 18(1):39-50.

Forward SE (2009) The theory of planned behaviour: the role of descriptive norms and past behaviour in the prediction of drivers' intentions to violate. Transport Res F: Traffic Psychol Behav 12(3):198-207.

Fraenkel J, Wallen N (2003) The nature of qualitative research. How to design and evaluate research in education, pp 429-449.

Fredricks AJ, Dossett DL (1983) Attitude-behavior relations: a comparison of the Fishbein-Ajzen and the Bentler-Speckart models. J Pers Soc Psychol 45(3):501.

Gefen D, Straub D, Boudreau M-C (2000) Structural equation modeling and regression: guidelines for research practice. Commun Assoc Inf Syst 4(1):7.

George, P. R. (2008). Utilizing the theory of planned behavior to explain suicidal intent.

Hagger MS, Chatzisarantis N, Biddle SJ (2001) The influence of self-efficacy and past behaviour on the physical activity intentions of young people. J Sports Sci 19(9):711-725.

Hair JF, Black WC, Babin BJ, Anderson RE, Tatham RL (2006) Multivariate data analysis (Vol. 6). Pearson Prentice Hall, Upper Saddle River.

Hair JF, Ringle CM, Sarstedt M (2011) PLS-SEM: indeed a silver bullet. J Mark Theory Pract 19(2):139-152.

Hair JF, Sarstedt M, Ringle CM, Mena JA (2012) An assessment of the use of partial least squares structural equation modeling in marketing research. J Acad Mark Sci 40(3):414-433.

Hair JF Jr, Hult GTM, Ringle C, Sarstedt M (2013) A primer on partial least squares structural equation modeling (PLS-SEM). Thousand Oaks: Sage Publications.

Heath C, Soll JB (1996) Mental budgeting and consumer decisions. J Consum Res 23:40-52.

Henderson PW, Peterson RA (1992) Mental accounting and categorization. Organ Behav Hum Decis Process 51(1):92-117.

Henseler J, Ringle CM, Sinkovics RR (2009) The use of partial least squares path modeling in international marketing. Adv Int Mark 20(1):277-319.

Honkanen P, Olsen SO, Verplanken B (2005) Intention to consume seafood - the importance of habit. Appetite 45(2):161-168.

Hulland J, Ryan MJ, Rayner RK (2010) Modeling customer satisfaction: a comparative performance evaluation of covariance structure analysis versus partial least squares, in Handbook of Partial Least Squares: Concepts, Methods and Application. Esposito Vinzi, V., Chin, W.W.; Henseler, J., Wang, H. (Eds.). Germany: Springer, (pp. 307-325).

JACKSON C, SMITH A, CONNER M (2003) Applying an extended version of the theory of planned behaviour to physical activity. J Sports Sci 21(2):119-133.

Jalilvand MR, Samiei N (2012) The impact of electronic word of mouth on a tourism destination choice: testing the theory of planned behavior (TPB). Internet Res Electron Network App Policy 22(5):591-612. https://doi.org/10.1108/ 10662241211271563.

Kashif M, Zarkada A, Ramayah T (2018) The impact of attitude, subjective norms, and perceived behavioural control on managers' intentions to behave ethically. Total Qual Manag Bus Excell 29(5-6):481-501.

Kautonen T, van Gelderen M, Fink M (2015) Robustness of the theory of planned behavior in predicting entrepreneurial intentions and actions. Entrepreneurship Theory and Pract 39(3):655-674. https://doi.org/10.1111/etap.12056.

Kidwell B, Brinberg D, Turrisi R (2003) Determinants of money management behavior. J Appl Soc Psychol 33(6):1244-1260.

Kidwell B, Turrisi R (2004) An examination of college student money management tendencies. J Econ Psychol 25(5):601-616.

Kim YJ, Njite D, Hancer M (2013) Anticipated emotion in consumers' intentions to select eco-friendly restaurants: augmenting the theory of planned behavior. Int J Hosp Manag 34(0):255-262. https://doi.org/10.1016/j.jihm.2013.04.004.

Kivetz R (1999) Advances in research on mental accounting and reason-based choice. Mark Lett 10(3):249-266.

Martin RJ, Usdan S, Nelson S, Umstattd MR, LaPlante D, Perko M, Shaffer H (2010) Using the theory of planned behavior to predict gambling behavior. Psychol Addict Behav 24(1):89.

Mathieson K (1991) Predicting user intentions: comparing the technology acceptance model with the theory of planned behavior. Inf Syst Res 2(3):173-191.

Norman P, Smith L (1995) The theory of planned behaviour and exercise: an investigation into the role of prior behaviour, behavioural intentions and attitude variability. Eur J Soc Psychol 25(4):403-415.

Nunnally JC (1978) Psychomtietric theory. McGraw-Hill, New York.

Nunnally JC, Bernstein I (1994) The assessment of reliability. Psychometric Theory 3(1):248-292.

Pan JY, Truong D (2018) Passengers' intentions to use low-cost carriers: an extended theory of planned behavior model. J Air Transp Manag 69:38-48.

Peter JP (1979) Reliability: a review of psychometric basics and recent marketing practices. J Mark Res 16(1):6-17.

Prelec D, Loewenstein G (1998) The red and the black: mental accounting of savings and debt. Mark Sci 17(1):4-28.

Read D, Loewenstein G, Rabin M (1999) Choice bracketing, Journal of Risk and Uncertainty 19, 171-197.

Rhodes RE, Courneya KS (2003) Investigating multiple components of attitude, subjective norm, and perceived control: an examination of the theory of planned behaviour in the exercise domain. Br J Soc Psychol 42(1):129-146.

Rivis A, Sheeran P, Armitage CJ (2006) Augmenting the theory of planned behaviour with the prototype/willingness model: predictive validity of actor versus abstainer prototypes for adolescents' health-protective and health-risk intentions. $\mathrm{Br} J$ Health Psychol 11(3):483-500.

Shafir E, Thaler RH (2006) Invest now, drink later, spend never: on the mental accounting of delayed consumption. J Econ Psychol 27(5):694-712

Shahid lqbal M, UI Hassan M, Habibah U (2018) Impact of self-service technology (SST) service quality on customer loyalty and behavioral intention: the mediating role of customer satisfaction. Cogent Business Manag 5(1):1. 
Sheeran P, Orbell S (1996) How confidently can we infer health beliefs from questionnaire responses? Psychol Health $11(2)$ : 273-290.

Sheeran P, Orbell S (2000) Using implementation intentions to increase attendance for cervical cancer screening. Health Psychol 19(3):283.

Sheeran P, Taylor S (1999) Predicting intentions to use condoms: a meta-analysis and comparison of the theories of reasoned action and planned Behavior1. J Appl Soc Psychol 29(8):1624-1675.

Shefrin HM, Thaler RH (1988) The behavioral life-cycle hypothesis. Econ Inq 26(4):609-643.

Soman D (2001) The mental accounting of sunk time costs: why time is not like money. J Behav Decis Mak 14(3):169-185.

Soman D (2003) The effect of payment transparency on consumption: quasi-experiments from the field. Mark Lett 14(3):173-183.

Soman D, Lam VM (2002) The effects of prior spending on future spending decisions: the role of acquisition liabilities and payments. Mark Lett 13(4):359-372.

Sutter N, Paulson S (2017) Predicting college students' intention to graduate: a test of the theory of planned behavior. Coll Stud J 50(3):409-421.

Tariq J, Sajjad A, Usman A, Amjad A (2017) The role of intentions in facebook usage among educated youth in Pakistan: an extension of the theory of planned behavior. Comput Hum Behav 74:188-195.

Thaler RH (1985) Mental accounting and consumer choice. Mark Sci 4(3):199-214.

Thaler RH (1999) Mental accounting matters. J Behav Decis Mak 12(3):183-206.

Thaler RH, Johnson EJ (1990) Gambling with the house money and trying to break even: the effects of prior outcomes on risky choice. Manag Sci 36(6):643-660.

Trafimow D, Borrie WT (1999) Influencing future behavior by priming past behavior: a test in the context of petrified Forest National Park. Leis Sci 21(1):31-42.

Triandis HC (1980) Reflections on trends in cross-cultural research. J Cross-Cult Psychol 11(1):35-58.

Verbeke W, Vackier I (2005) Individual determinants of fish consumption: application of the theory of planned behaviour. Appetite 44(1):67-82.

Warshaw PR, Davis FD (1984) Self-understanding and the accuracy of behavioral expectations. Personal Soc Psychol Bull 10(1):111-118

Xiao JJ, Fan JX (2002) A comparison of saving motives of urban Chinese and American workers. Fam Consum Sci Res J 30(4):463-495.

\section{Submit your manuscript to a SpringerOpen ${ }^{\circ}$ journal and benefit from:}

- Convenient online submission

- Rigorous peer review

- Open access: articles freely available online

High visibility within the field

- Retaining the copyright to your article

Submit your next manuscript at $\boldsymbol{\nabla}$ springeropen.com 